\title{
FAKTOR-FAKTOR YANG MEMPENGARUHI KEPUASAN NASABAH BPRS BANGUN DRAJAT WARGA YOGYAKARTA PERSPEKTIF EKONOMI ISLAM
}

\author{
AYESHA NUR SALMA, Se.,Sy.,M.E \\ Program Studi Ekonomi Syariah FEB UMPP \\ magisteryesha93@gmail.com
}

\begin{abstract}
Abstraksi
Persaingan di dunia bisnis sekarang sudah semakin ketat. Hal ini juga dirasakan oleh dunia perbankan. Pada perbankan khususnya BPR Syariah tentunya memiliki target untuk meningkatkan perkembangan perusahaannya yaitu dengan mengukur seberapa besar kepuasan nasabahnya. Agar nasabah merasa puas dan tidak berpindah ke tempat lain, maka perusahaan harus mengetahui faktor-faktor yang mempengaruhi kepuasan nasabahnya. Kepuasan nasabah dapat diciptakan melalui kualitas produk, kualitas pelayanan dan harga. Namun dalam hal ini, kepuasan nasabah disini yang akan ditinjau adalah melalui perspektif ekonomi Islam karena ingin melihat sejauh mana kemampuan BPR Syariah tersebut dalam menerapkan prinsip-prinsip dan sistem syariah yang telah ditetapkan. Tujuan dari penelitian ini untuk melihat atau mengetahui seberapa besar pengaruh kualitas produk, kualitas pelayanan, dan harga terhadap kepuasan nasabah perspektif ekonomi Islam.

Penelitian ini dilakukan di BPR Syariah Bangun Drajat Yogyakarta yang populasi nasabahnya sebanyak 844 orang dan setelah menggunakan rumus Slovin maka didapat sampel yang digunakan untuk penelitian ini sebanyak 89 orang. Kemudian dilakukan analisis terhadap data-data yang diperoleh berupa analisis kuantitatif. Analisis kuantitatif meliputi uji validitas dan uji reliabilitas, uji asumsi klasik, uji regresi linear berganda, uji Goodness of Fit melalui koefisien regresi ( ), uji simultan (F), dan uji parsial (t). Hasil penelitian ini menunjukkan bahwa semua variabel independen yang diuji berpengaruh secara positif dan signifikan terhadap kepuasan nasabah. Berdasarkan hasil penelitian ini dapat diketahui bahwa kualitas produk berpengaruh terhadap kepuasan nasabah dengan nilai thitung sebesar 2,015 dengan sig. $t$ sebesar 0,047 ( $p<$ $0,05)$, kualitas pelayanan dengan nilai $t$ hitung sebesar 2,002 dengan sig. $t$ sebesar $0.049(p<0,05)$, dan harga dengan nilai thitung sebesar 2,892 dengan sig. $t$ sebesar $0,005(p<0,05)$.
\end{abstract}

Kata Kunci: Kualitas Produk, Kualitas Pelayanan, Harga, Perspektif Ekonomi

\section{A. Latar Belakang Penelitian}

Lembaga keuangan adalah sebuah wadah di mana terdapat jasa dalam proses mengelola keuangan untuk tujuan tertentu. Seperti yang kita tahu, peranan lembaga keuangan dalam kehidupan terutama bank sangatlah penting. Hal ini akibat semakin berkembangnya faktor ketataniagaan yang mau tidak mau melibatkan lembaga keuangan atau bank di dalamnya. Namun pesatnya perkembangan bank tidak diimbangi dengan pesatnya kesejahteraan masyarakat, terutama masyarakat yang tergolong ekonomi lemah yang biasanya terdapat di wilayah desa atau kecamatan. Pada umumnya bank 
konvensional sangat selektif dan hanya berorientasi untuk mendapat keuntungan dengan sedikit resiko, oleh karenanya masyarakat ekonomi lemah sulit untuk mendapat jasa keuangan bank.

Dalam upayanya untuk merangkul masyarakat ekonomi lemah, pemerintah juga mengatur untuk didirikannya Bank Perkreditan Rakyat yang lingkup kerjanya lebih terpusat pada wilayah tertentu saja, misalnya di kabupaten, kecamatan dan desa. Hal ini bertujuan agar semakin meratanya layanan jasa keuangan bagi seluruh masyarakat. Praktek bunga yang diterapkan setiap bank, baik bank umum ataupun bank perkreditan rakyat tetap menjadi andalan dalam rangka mencari keuntungan. Sistem bunga yang diterapkan bank akhirnya mendapat respon dari kaum muslim, yang mana sudah jelas bahwa bunga/riba adalah haram hukumnya. Maka dengan munculnya pemikiran untuk mendirikan bank yang berprinsip syariah secara nasional terlebih dahulu didirikan sebuah lembaga keuangan yaitu bank perkreditan rakyat syariah pada tahun 1990. Diharapkan bahwa berdirinya bank perkreditan rakyat syariah menjadi salah satu solusi dalam rangka melayani jasa keuangan yang bebas dari praktek riba sehingga kesejahteraan masyarakat akan semakin meningkat.

Bank Perkreditan Rakyat Syariah (BPRS) adalah salah satu lembaga keuangan perbankan syariah, yang pola operasionalnya mengikuti prinsipprinsip syariah ataupun muamalah Islam. BPR Syariah didirikan sebagai langkah aktif dalam restrukturisasi perekonomian Indonesia yang dituangkan dalam berbagai paket kebijaksanaan keuangan, moneter, dan perbankan secara umum, dan secara khusus mengisi peluang terhadap kebijaksanaan Bank Konvensional dalam penetapan tingkat suku bunga (rate of interest). Selanjutnya BPR Syariah secara luas dikenal sebagai faktor perbankan bagi hasil atau faktor perbankan Islam.

BPR Syariah terfokus untuk melayani Usaha Mikro dan Kecil yang menginginkan proses mudah, pelayanan cepat dan persyaratan ringan. BPR Syariah memiliki petugas yang berfungsi sebagai armada antar jemput setoran dan penarikan tabungan/deposito termasuk setoran angsuran pembiayaan. Pelayanan ini sangat relevan dengan kebutuhan masyarakat UMK yang cenderung tidak bisa meninggalkan usaha kesehariannya di pasar/toko/rumah. Prinsip syariah dalam BPR Syariah diberlakukan untuk transaksio pendanaan (tabungan dan deposito) maupun pembiayaan (pinjaman). BPR Syariah mengelola dana masyarakat dengan faktor bagi hasil. Dengan faktor bagi hasil, masyarakat penyimpan dana akan mendapatkan bagi hasil secara fluktuasi karena sangat bergantung kepada pendapatan yang diperoleh BPR Syariah. Untuk itu, perlu disepakati nisbah (porsi) di awal transaksi. Setiap tabungan maupun deposito yang disimpan di BPR Syariah mendapat jaminan dari Lembaga Penjamin Simpanan (LPS), sepanjang sesuai ketentuan yang berlaku, sehingga masyarakat akan tetap merasa aman untuk menyimpan dananya di BPR Syariah.

BPRS Bangun Drajat Warga merupakan salah satu Lembaga Keuangan Syariah yang telah berdiri sejak tahun 1993. Maksud dan tujuan Perseroan, 
menjalankan usaha dalam bidang usaha sebagai Bank Pembiayaan Rakyat yang semata - mata akan beroperasi dengan sistim bagi hasil, baik terhadap debitur maupun krediturnya, menghimpun dana dari masyarakat dalam bentuk deposito berjangka dan tabungan, memberikan pembiayaan bagi pengusaha kecil dan / atau masyarakat pedesaan. Adapun produk pendanaan yaitu tabungan yang memiliki berbagai variasi produk yaitu tabungan iB amanah dan tabungan mudharabah. Selain itu ada produk pembiayaan yaitu deposito dengan beberapa produk diantaranya deposito iB BDW 1 bulan, deposito iB BDW 3 bulan, deposito iB BDW 6 bulan, deposito iB BDW 12 bulan (Bangun Drajat Warga).

Pemilihan penelitian pada lembaga tersebut di karenakan pembentukan BPRS Bangun Drajat Warga didasari motivasi untuk memasyarakatkan keuangan syariah yang belum popular kala itu. Belum populernya keuangan berbasis syariah membuat perjuangan BPRS Bangun Drajat Warga cukup berat, namun setelah melalui perjuangan yang berat, BPRS Bangun Drajat Warga menjadi lembaga keuangan yang solid. Saat ini ada lebih dari 10.000 nasabah. Kemajuan bisnis membuat BPRS Bangun Drajat Warga memiliki satu kantor cabang di Bantul dan dua kantor kas yang berada di Baturetno, Bantul dan jalan Wates. Pada 2016 kemarin, BPRS Bangun Drajat Warga akan kembali membuka kantor cabang di Jogja dan akan mulai inisiasi di Gunungkidul.

Pada BPRS Bangun Drajat Warga Yogyakarta ini sangat memperhatikan untuk memaksimalkan kepuasan nasabah. Namun, dalam hal ini BPRS Bangun Drajat Warga Yogyakarta sendiri memilik berberapa faktor yang menjadi hambatan untuk menciptakan tujuan tersebaut. Masalah yang dihadapi pada bank ini yaitu adanya ketidaksesuaian harapan dan realita terhadap penggunaan produk yang ditawarkkan, beberapa kompalin dari nasabah yang merasa kurang puas dengan pelayanan yang maksimal seperti halnya kurang memberikan waktu yang optimal, kurang ramah dalam melayani nasabah. Begitupula dengan harga yang di tetapkan pada BPRS Bangun Drajat Warga terbentur pada kebijakan penetapan harga, dan masih menerapkan sistem bunga walaupun tidak terlalu besar.

Dari BPRS tersbut, bukan hanya di lihat dari segi produk tetapi juga dari harga dan pelayanan yang di berikan kepada nasabah. Dengan adanya kualitas produk, kulaitas pelayanan dan harga, itu sangat mempengaruhi persaingan antar lembaga. Perkembangan dan peningkatan jasa pelayanan pada bank dari tahun ke tahun semakin menjadi perhatian masyarakat. Hal ini dapat dilihat dari adanya persaingan yang ketat dalam hal kualitas pelayanan dan promosi. Dengan banyaknya jumlah BPR Syariah yang ada di Indonesia, persaingan antar lembaga akan semakin tinggi, maka setiap BPR Syariah akan berusaha untuk memberikan yang terbaik untuk nasabah dan calon nasabahnya.

Dalam persaingan tersebut perlu kiranya pemilik perusahaan menjaga kualitas produk yang di jual. Hal ini dikarenakan pada saat ini sebagian nasabah telah merubah pola fikirnya dalam mengkonsumsi suatu produk. Nasabah tidak hanya melihat dari terpenuhinya kebutuhan mereka, Nasabah melihat suatu produk apakah dapat memenuhi harapannya atau mungkin 
melebihi dari apa yang mereka harapkan. Nasabah menilai produk dan kualitas produk tersebut. Semakin baik produk yang di jual perusahaan maka akan memberi pengaruh positif terhadap kepuasan nasabah pengguna produk dalam perusahaan tersebut. Selain itu, nasabah saat ini juga mulai melakukan penilaian terhadap kualitas pelayanan yang diberikan dalam suatu perusahaan dan citra perusahaan yang timbul di ingatan nasabah baik sebelum atau sudah melakukan proses transaksi. Apabila pelayanan yang diterima dan citra sebuah perusahaan cukup baik di mata nasabah, tidak jarang nasabah perusahaan tersebut enggan untuk berpindah.

Dalam kondisi persaingan yang ketat tersebut, hal utama yang diprioritaskan oleh perusahaan yang bergerak dalam bidang pelayanan adalah kepuasan nasabah agar dapat bertahan yang mengakibatkan peningkatan loyalitas untuk menguasai pasar. Begitu juga kualitas pelayanan yang diberikan oleh bank syariah yang bisa memberikan kepuasan kepada nasabah bank tersebut. Perusahaan dituntut berusaha membuat nasabah merasa puas dengan memberikan penawaran dan pelayanan yang lebih baik, mengingat perusahaan harus mampu untuk dapat mempertahankan posisi pasarnya ditengah persaingan yang semakin ketat. Salah satunya dengan mengembangkan strategi untuk mempertahankan nasabah melalui kualitas jasa. Strategi yang ditempatkan untuk dapat mempertahankan kepuasan nasabah adalah dengan menyediakan jasa layanan yang berkualitas, sehingga disini pihak manajemen perusahaan harus memperhatikan kualitas produk maupun kualitas pelayanan.

Perusahaan mampu dituntut menawarkan barang atau jasa dengan mutu atau pelayanan yang diberikan kepada nasabah dari waktu ke waktu, karena nasabah yang semkain pandai dan terdidik, menyebabkan keinginan dan kebutuhan berubah sangat cepat. Perusahaan sudah semestinya berorientasi pada nasabah, agar dapat memenangkan persaingan. Dengan memberikan kepuasan pada nasabah akan membangun kesetiaan pada nasabah dan akhirnya dapat menciptakan hubungan yang erat antara nasabah dengan perusahaan. Kepuasan nasabah merupakan salah satu faktor penting dalam memenangkan persaingan, sehingga setiap perusahaan berusaha mengoptimalkan segala faktor yang dapat meningkatkan nilai kepuasan pada nasabah.

Agar dapat bersaing, bertahan hidup, dan berkembang, maka perusahaan dituntut untuk mampu memenuhi kebutuhan dan keinginan nasabah dengan memberikan pelayanan yang terbaik dan berkualitas, maka dengan begitu nasabah akan merasa mendapat kepuasan tersendiri dan merasa dihargai sehingga mereka senang dan bersedia untuk menjadi nasabah tetap. Begitu pula dengan harga, harga merupakan salah satu unsur yang mempengaruhi kegiatan-kegiatan dalam perusahaan yang berfungsi menciptakan keunggulan kompetitif bagi perusahaan. Namun, hal itu seringkali terbentur pada kebijakan penetapan harga. Penetapan harga oleh perusahaan harus disesuaikan dengan situasi lingkungan dan perubahan yang terjadi terutama pada saat persaingan yang semakin ketat dan perkembangan permintaan yang terbatas. Dalam iklim persaingan yang ketat seperti sekarang 
ini, perusahaan harus memperhatikan faktor harga, karena besar kecilnya harga yang ditetapkan akan sangat mempengaruhi kemampuan perusahaan dalam bersaing dan juga mampu mempengaruhi nasabah untuk membeli produknya. Agar lebih kompetitif di pasar, perusahaan dapat mempertimbangkan harga pesaing sebagai pedoman dalam menentukan harga jual produknya.

Dalam hal tersebut beberapa faktor dalam menentukan kepuasan nasabah yang sudah dijelaskan di atas, tidak hanya dilihat dalam segi konvensional tetapi disini dikhususkan untuk meninjau lebih dalam melalui perspektif ekonomi Islam. Tinjauan dari segi ekonomi Islam bertujuan untuk melihat kemampuan suatu perusahaan dalam mengelola atau menjalan visi dan misinya dalam kesesuaian aturan, prinsip-prinsip dan sistem syariah yang telah ditetapkan pada perusahaan tersebut.

Berdasarkan uraian di atas penulis tertarik melakukan penelitian untuk mengetahui sejauh mana kualitas produk, kualitas pelayanan dan harga yang berpengaruh terhadap kepuasan nasabah di BPRS Bangun Drajat Warga Yogyakarta. Untuk itu penulis melakukan penelitian dengan judul: “ Pengaruh Kualitas Produk, Kualitas Pelayanan, dan Harga Terhadap Kepuasan Nasabah BPRS Bangun Drajat Warga Yogyakarta Perspektif Ekonomi Islam".

\section{B. Rumusan Masalah}

Rumusan masalah merupakan langkah yang sangat penting karena akan menggambarkan ruang lingkup dalam penelitian. Bertolak dari latar belakang penelitian yang telah dipaparkan, maka dapat dirumuskan masalah tersebut dirinci ke dalam pertanyaan penelitian sebagai berikut :

1. Bagaimana pengaruh faktor-faktor seperti kualitas produk, kualitas pelayanan, dan harga terhadap kepuasan nasabah BPRS Bangun Drajat Warga Yogyakarta perspektif ekonomi Islam?

2. faktor-faktor apa yang memiliki pengaruh paling dominan terhadap kepuasan nasabah BPRS Bangun Drajat Warga Yogyakarta?

3. Bagaimana faktor-faktor seperti kualitas produk, kualitas pelayanan, dan harga secara bersama-sama mempengaruhi kepuasan nasabah BPRS Bangun Drajat Warga Yogyakarta?

\section{Tujuan}

Dalam pembuatan penelitian ini tujuan yang penulis harapkan dari penelitian adalah untuk:

1. Menjelaskan pengaruh faktor-faktor seperti kualitas produk, kualitas pelayanan dengan prinsip syariah, dan harga terhadap kepuasan nasabah BPRS Bangun Drajat Warga Yogyakarta.

2. Menjelaskan faktor-faktor yang paling dominan mempengaruhi kepuasan nasabah BPRS Bangun Drajat Warga Yogyakarta.

3. Menjelaskan faktor-faktor seperti kualitas produk, kualitas pelayanan, dan harga secara bersama-sama mempengaruhi kepuasan nasabah BPRS Bangun Drajat Warga Yogyakarta. 


\section{Telaah Pustaka}

Berdasarkan pada pencarian literatur yang dilakuakn penulis, penulis tidak menemukan penelitian atau jurnal yang membahas tentang Analisis Pengaruh Kualitas Produk dan Kualitas Pelayanan dengan Prinsip Syariah Terhadap Kepuasan Nasabah Pada BPRS Bangun Drajat Warga Yogyakarta. Tetapi disini penulis menemukan literatur pendukung yang relevan untuk dijadikan obyek penelitian. Ada beberapa peneliti terdahulu yang sudah dilakukan berkaitan dengan pengaruh kualitas produk dan kualitas layanan terdapat 3 peneliti, yakni:

Pertama, penelitian yang dilakukan oleh Danny Wibowo dengan judul "Dimensi Nilai Jasa Bank Terhadap Kepuasan Nasabah Dan Dampaknya Pada Loyalitas (Studi Pada Bank Bca Cabang Surabaya)". Tujuan dari penelitian ini adalah untuk mengetahui dan menganalisis pengaruh secara langsung maupun tidak langsung antara variabel dimensi nilai jasa bank (tingkat suku bunga, fasilitas, karyawan, kewajiban, proses, perasaan aman dan manfaat) terhadap loyalitas yang dimediasi variabel kepuasan nasabah Bank BCA Darmo Cabang Surabaya. Jenis penelitiannya adalah Data primer yaitu data yang diperoleh dari hasil observasi, wawancara dan pertemuan dengan objek serta jawaban responden atas daftar pertanyaan yang disebarkan dan data sekunder, yaitu data yang diperoleh dari data intern perusahaan, jurnal-jurnal, buku-buku yang berkaitan dengan obyek penelitian. Metode pengumpulan data yaitu dengan melakukan penelitian lapangan yang bertujuan mendapatkan data empiris untuk pengujian hipotesis. Pendekatan analisis dalam penelitian ini adalah kuantitatif. Hasil studi menunjukkan analisis two stage least square menunjukkan bahwa dimensi nilai jasa bank berpengaruh langsung terhadap loyalitas nasabah dan dapat juga berpengaruh tidak langsung (dimensi nilai jasa bank berpengaruh terhadap loyalitas nasabah yang dimediasi oleh variabel kepuasan nasabah). Kata kunci: Dimensi nilai jasa bank, kepuasan nasabah, loyalitas.

Kedua, penelitian yang dilakukan oleh Shandy Widjoyo dengan judul "Pengaruh Kualitas Layanan dan Kualitas Produk Terhadap Kepuasan Pelanggan dan Loyalitas Konsumen Restoran Happy Garden". Menunjukkan bahwa Perkembangan bisnis makanan di Indonesia yang semakin berkembang pesat juga menyebabkan meningkatnya persaingan. Sebagai salah satu restoran, Happy Garden harus memiliki keunggulan untuk mampu bersaing agar dapat bertahan dan memenangkan persaingan dalam bisnis makanan ini. Salah satu cara yang dapat digunakan untuk mencapai keunggulan tersebut adalah dengan menerapkan kualitas layanan dan kualitas produk yang tepat sehingga dapat meningkatkan kepuasan pelanggan dan menciptakan loyalitas konsumen. Penelitian ini bertujuan untuk menganalisa pengaruh dari kualitas layanan dan kualitas produk terhadap kepuasan pelanggan dan loyalitas konsumen di restoran Happy Garden Surabaya serta mengetahui faktor mana yang berpengaruh dominan di restoran tersebut. Dalam pengumpulan data, peneliti menyebarkan kuesioner kepada 160 responden yang merupakan konsumen dari Happy Garden Surabaya. Alat analisa yang digunakan untuk 
mengukur pengaruh Kualitas Layanan dan Kualitas Produk terhadap Kepuasan Pelanggan dan Loyalitas Konsumen adalah Structural Equation Model (SEM).

Ketiga, penelitian yang dilakukan oleh Randy Christian dengan judul "Pengaruh Kualitas Layanan Rumah Makan Bromo Asri Terhadap Kepuasan Pelanggan". Menunjukkan bahwa Rumah makan Bromo Asri yang berlokasi di Probolinggo sangat populer di kalangan wisatawan yang melakukan perjalanan dari dan ke Bali. Namun, dalam industri restoran yang sangat kompetitif saat ini, Bromo Asri harus menjaga tingkat kualitas layanan. Penelitian ini diadakan untuk mengukur tingkat kualitas layanan Bromo Asri terhadap kepuasan pelanggan. Ada 100 responden yang berkontribusi dalam penelitian ini. Kriteria responden adalah berusia di atas 17 tahun dan sudah datang ke Bromo Asri dua kali dalam 6 bulan terakhir.

Penelitian ini mengungkapkan bahwa semua dimensi kualitas pelayanan yang tangibles, reliability, responsiveness, assurance, dan empathy berpengaruh signifikan positif terhadap kepuasan pelanggan.

\section{Kerangka Teori}

1. Teori Produk

a. Definisi Produk

Pengertian produk menurut (Simamora H. , 2000) adalah sesuatu yang diterima oleh konsumen atau pembeli atau pemakai industrial pada saat melakukan pembelian atau menggunakan produk, secara formal dapat dikatakan jumlah seluruh kepuasan fisik dan psikologis yang dinikmati oleh pembeli sebagai akibat pembelian dan atau penggunaan sebuah produk.

\section{b. Kualitas Produk}

Kualitas produk merupakan kemampuan dari suatu produk dalam menjalankan fungsinya. Kualitas produk mempunyai hubungan yang sangat erat dengan kepuasan pelanggan karena kualitas produk dapat dinilai dari kemampuan produk tersebut untuk menciptakan kepuasan pelanggan. Semakin tinggi tingkat kualitas produk dalam memuaskan pelanggan, maka akan menyebabkan kepuasan pelanggan yang tinggi pula (Kotler, 2008).

\section{c. Kualitas Produk dalam Perspektif Islam}

Dalam Al Quran yang behubungan dengan hal konsumsi yaitu, gunakanlah barang-barang yang baik dan bermanfaat untuk memenuhi keinginan dan kebutuhan. Karena dengan barang-barang yang bermanfaat dan baik akan membawa ke perbuatan yang baik pula. Barang-barang yang bermanfaat dan baik disini yaitu yang memiliki kualitas baik. Sebagaimana yang tercantum dalam Al Quran surat Al-Baqarah ayat 168 :

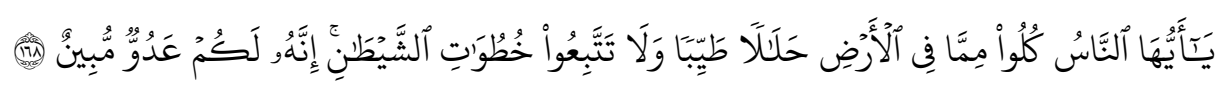


Artinya: "Hai sekalian manusia, makanlah yang halal lagi baik dari apa yang terdapat di bumi, dan janganlah kamu mengikuti langkah-langkah syaitan, karena sesungguhnya syaitan itu adalah musuh yang nyata bagimu (Al-Baqarah:168)"

\section{Kualitas Pelayanan}

Kualitas pelayanan merupakan totalitas bentuk dari karakteristik barang atau jasa yang menunjukkan kemampuannya untuk memuaskan kebutuhankebutuhan pelanggan, baik yang tampak jelas maupun tersembunyi (Kotler, 2008).

\section{Pelayanan Dalam Pandangan Islam}

Menurut (Tanjung, 2003) menyatakan terdapat nilai-nilai islami yang harus diterapkan dalam memberikan pelayanan yang maksimal, yaitu:

a. Profesional (Fathanaah)

"Profesional adalah bekerja dengan maksimal dan pernuk komitmen dan kesungguhan". Sifat profesionalisme digambarkan dalam Al-Quran surat At-Taubah ayat 105:

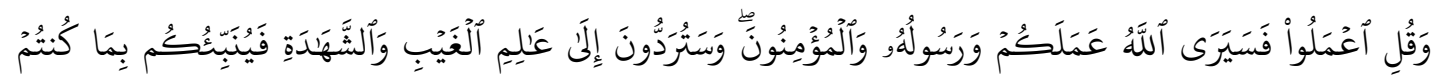

Artinya: "Bekerjalah kamu, maka Allah dan Rasul-Nya serta orang-orang mukmin akan melihat pekerjaanmu itu, dan kamu akan dikembalikan kepada (Allah) Yang Mengetahui akan yang ghaib dan yang nyata, lalu diberitakan-Nya kepada kamu apa yang telah kamu kerjakan".

b. Kesopanan dan Keramahan (Tabliqh)

Menurut (Kertajaya, 2006) "Tabliqh artinya komunikatif dan argumentatif". Orang yang memiliki sifat tabliqh akan menyampaikan dengan benar dan tutr kata yang tepat. Kesopanan dan keramahan merupakan initi dalam memberika pelayanan kepada orang lain.

Imam Ali as mengungkapkan dalam sebuah hadis tentang kesopanan yang berbunyi:

Artinya: "Kesantunan/tata-krama mencukupkan (kita) dari kedudukan (kehormatan) sosial."

c. Jujur (Sidik)

Jujur yaitu tidak pernah berdusta dalam melakukan segala kegiatan transaksi. Menurut (Kertajaya, 2006) "Jujur adalah kesesuaian antara berita yang disampaikan dan fakta, antara fenomenan dan yang di beritakan, serta bentuk dan substansi". Tidak menipu yaitu sikap yang sangat mulia dalam menjalankan bisnisnya adalah tidak pernah menipu seperti praktek bisnis dan dagang yang diterpkan oleh Rasulullah SAW adalah tidak pernah menipu. 


\section{Teori Harga}

\section{a. Definisi Harga}

Menurut (Philip, 2005) "Harga adalah jumlah uang yang harus dibayar pelanggan untuk produk itu." Sedangkan menurut (Simamora, 2003) "Harga adalah jumlah uang yang dibebankan atau dikenakan atas sebuah produk atau jasa." Menurut definisi diatas, kebijakan mengenai harga sifatnya hanya sementara, berarti produsen harus mengikuti perkembangan harga di pasar dan harus mengetahui posisi perusahaan dalam situasi pasar secara keseluruhan.

\section{b. Penetapan Harga Dalam Al-Qur'an dan Hadist}

Landasan hukum Islam yang terdiri dari ayat Al-Qur'an dan Al-Hadits Nabi SAW. telah memberikan ketentuan-ketentuan yang berkaitan dengan penetapan harga.

1) Firman Allah SWT. Dalam Q.S An-Nisa ayat 29

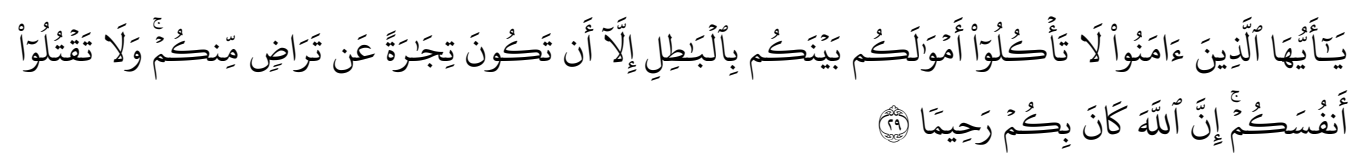

"Hai orang-orang yang beriman, janganlah kamu saling memakan harta sesamamu dengan jalan yang batil, kecuali dengan jalan perniagaan yang berlaku dengan suka sama-suka di antara kamu. Dan janganlah kamu membunuh dirimu; sesungguhnya Allah adalah Maha Penyayang kepadamu"

4. Kepuasan Nasabah

a. Definisi Kepuasan Nasabah

Wilikie mendefifisikan kepuasan konsumen sebagai suatu tanggapan emosional pada evaluasi terhadap pengalaman konsumsi suatu produk atau jasa (Wilkie, 2009).

\section{b. Kepuasan Nasabah Menurut Perspektif Islam}

Berbeda dengan konsep ekonomi konvensional yang menyatakan bahwa kepuasan konsumen terjadi bila kebutuhan yang bersifat fisik telah terpenuhi. Dalam Islam, kepuasan terjadi manakala telah terpenuhinya kebutuhan fisik maupun non fisik seseorang. Kebutuhan fisik bukan arti keinginan semata, tetapi kebutuhan yang memiliki nilai manfaat tertentu (berdasarkan pada tingkat kemaslahatan). Sedangkan kebutuhan non fisik berupa nilai ibadah yang didapati dari apa yang dilakukan. Untuk mencapai tingkat kepuasan dalam kegiatan konsumsi, Islam memberikan panduan, yaitu (Sudarsono, 2004):

a. Barang dikonsumsi tidak haram/halal

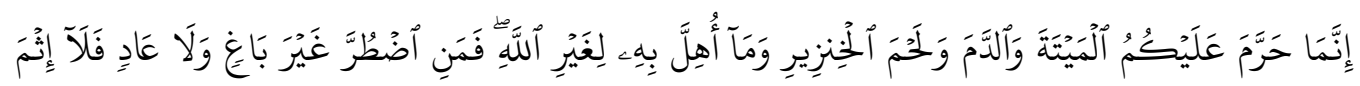

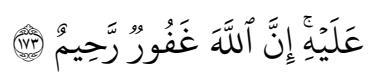


Artinya:"Sesungguhnya Allah hanya mengharamkan bagimu bangkai, darah, daging babi, dan binatang yang (ketika disembelih) disebut (nama) selain Allah. Tetapi barangsiapa dalam keadaan terpaksa (memakannya) sedang dia tidak menginginkannya dan tidak (pula) melampaui batas, maka tidak ada dosa baginya. Sesungguhnya Allah Maha Pengampun lagi Maha Penyayang". (QS Al Baqarah:173)

b. Cara memperolehnya tidak dengan spekulasi

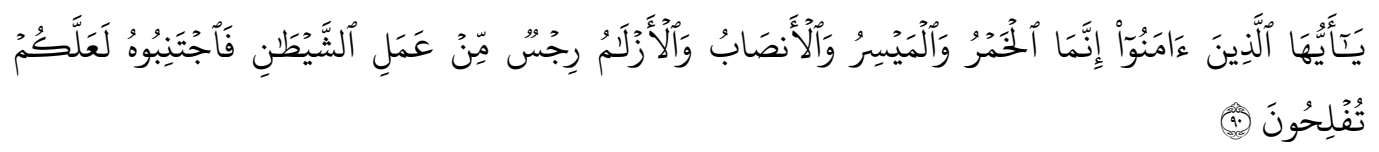

Artinya: "Hai orang-orang yang beriman, sesungguhnya (meminum) khamar, berjudi, (berkorban untuk) berhala, mengundi nasib dengan panah, adalah termasuk perbuatan syaitan. Maka jauhilah perbuatan-perbuatan itu agar kamu mendapat keberuntungan".(QS.Al-Maidah:90)

c. Tidak menimbun dan melakukan pasar gelap

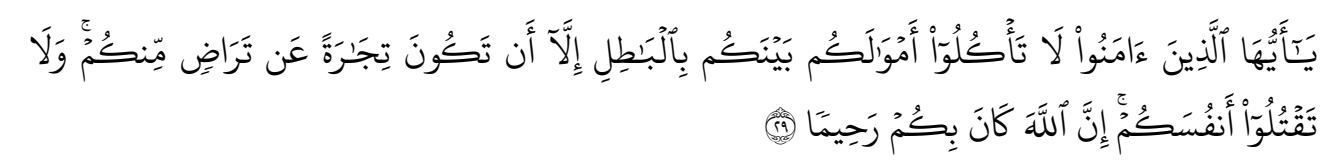

Artinya: "Hai orang-orang yang beriman, janganlah kamu saling memakan harta sesamamu dengan jalan yang batil, kecuali dengan jalan perniagaan yang berlaku dengan suka sama-suka di antara kamu. Dan janganlah kamu membunuh dirimu; sesungguhnya Allah adalah Maha Penyayang kepadamu". (QS. An-Nisa:29)

d. Tidak mengandung riba

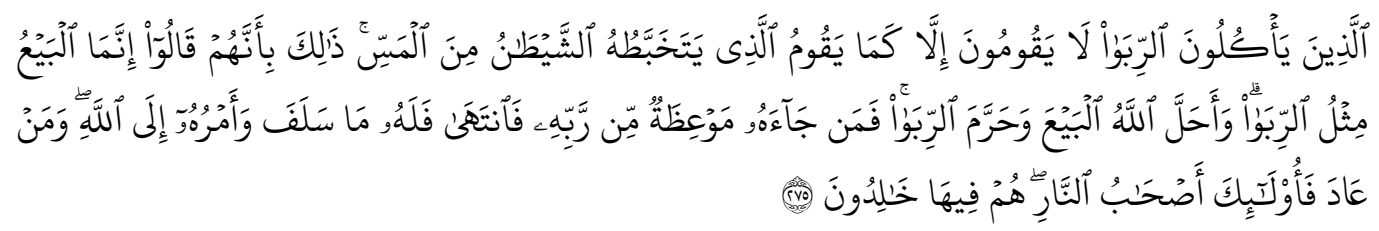

Artinya: "Orang-orang yang makan (mengambil) riba tidak dapat berdiri melainkan seperti berdirinya orang yang kemasukan syaitan lantaran (tekanan) penyakit gila. Keadaan mereka yang demikian itu, adalah disebabkan mereka berkata (berpendapat), sesungguhnya jual beli itu sama dengan riba, padahal Allah telah menghalalkan jual beli dan mengharamkan riba. Orang-orang yang telah sampai kepadanya larangan dari Tuhannya, lalu terus berhenti (dari mengambil riba), maka baginya apa yang telah diambilnya dahulu (sebelum datang larangan); dan urusannya (terserah) kepada Allah. Orang yang kembali (mengambil riba), maka orang itu adalah penghuni-penghuni neraka; mereka kekal di dalamnya". (QS. AlBaqarah:275)

e. Memperhitungkan akat dan infak

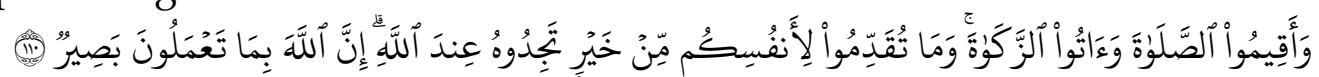


Artinya: "Dan dirikanlah shalat dan tunaikanlah zakat. Dan kebaikan apa saja yang kamu usahakan bagi dirimu, tentu kamu akan mendapat pahala nya pada sisi Allah. Sesungguhnya Alah Maha Melihat apa-apa yang kamu kerjakan". (QS. AlBaqarah:110)

\section{METODE PENELITIAN}

\section{A. Desain Penelitian}

Penelitian ini merupakan penelitian yang berbentuk penelitian lapangan (field research), dimana data dan informasinya diperoleh dari kegiatan lapangan penelitian. Metode penelitian yang digunakan untuk menjelaskan penelitian ini menggunakan metode penelitian kuantitatif. Metode kuantitatif diartikan sebagai metode penelitian yang berlandaskan pada filsafat positivisme yang digunakan untuk meneliti pada populasi atau sampel tertentu, pengumpulan data menggunakan instrumen penelitian, analisis data bersifat kuantitatif/statistik, dengan tujuan untk menguji hipotesis yang telah ditetapkan. Adapun sifat hubungan antar variabel dalam penelitian ini menggunakan hubungan kausal yang merupakan hubungan yang bersifat sebab akibat, dimana ada variabel independen (variabel yang mempengaruhi) dan variabel dependen (dipengaruhi)

\section{B. Lokasi Penelitian}

Ditinjau dari segi lokasi penelitian, penelitian ini dilakukan di BPRS Bangun Drajat Warga Yogyakarta jalan Gedongkuning Selatan 131 Yogyakarta.

\section{Waktu pelaksanaan penelitian}

Pelaksanaan penelitian akan di laksanakan pada bulan Maret sampai bulan April 2017.

\section{Obyek Penelitian}

Obyek penelitian yang akan di teliti oleh peniliti yaitu nasabah pada BPRS Bangun Drajat Warga Yogyakarta.

\section{E. Populasi dan Sampel}

Ferdinan mendefinisikan populasi adalah generalisasi yang terdiri atas obyek atau subyek yang memiliki kualitas dan karakteristik tertentu yang ditetapkan oleh peneliti untuk dipelajari dan kemudian ditarik kesimpulan (Ferdinand,2006). Populasi dalam penelitian ini yaitu 844 nasabah BPRS Bangun Drajat Warga Yogyakarta.

Bila jumlah populasi besar dan tidak mungkin dilakukan penelitian terhadap seluruh anggota populasi maka dapat menggunakan sampel yang diambil dari populasi tersebut. Menurut (Sugiyono, 2010) mengemukakan bahwa "Sampel adalah bagian dari jumlah dan karakteristik yang dimiliki oleh populasi tersebut."

Sampel dalam penelitian ini adalah 89 nasabah BPRS Bangun Drajat Warga Yogyakarta dengan menggunakan rumus Slovin.

Sumber data dari penelitian ini yaitu dari data primer. Data primer dalam penelitian ini diperoleh dengan cara melakukan menyebarkan kuesioner kepada responden. Metode yang dapat digunakan untuk mengumpulkan data 
primer yaitu melalui penyebaran kuesioner, dan observasi secara langsung kepada individu atau perseorangan.

\section{F. Teknik Pengumpulan Data}

Metode pengumpulan data pada penelitian ini menggunakan kuesioner, yaitu teknik pengumpulan data yang dilakukan dengan cara memberi seperangkat pertanyaan atau pernyataan tertulis kepada responden untuk dijawab.

\section{HASIL DAN PEMBAHASAN}

Dalam pembahasan ini telah di dapatkan hasil dari penelitian berdasarkan olah data yang penyusun lakukan yaitu:

A. Pengaruh Kualitas Produk, Kualitas Pelayanan, dan Harga Terhadap Kepuasan Nasabah Perspektif Ekonomi Islam

1. Pengaruh Kualitas Produk Terhadap Kepuasan Nasabah BPRS Bangun Drajat Warga Yogyakarta

Hasil pengujian signifikansi menunjukkan bahwa terdapat nilai probabilitas sebesar 0,047 $(0,047<0,05)$. Nilai tersebut dapat membuktikan Ha1 diterima, yang berarti bahwa "Kualitas Produk berpengaruh terhadap kepuasan nasabah".

Kualitas produk merupakan hal yang penting yang harus diusahakan oleh setiap perusahaan jika ingin yang dihasilkan dapat bersaing di pasar untuk memuaskan kebutuhan dan keinginan konsumen. Semakin bertambah dewasanya pikiran konsumen dalam mempertimbangkan kualitas suatu produk yang dipilihnya, sehingga menuntut perusahaan untuk selalu memperbaiki kualitas produk mereka. Tingkat kepuasan pelanggan sangat bergantung pada mutu suatu produk. Tingkat kualitas yang tinggi akan menghasilkan kepuasan pelanggan yang tinggi. Dengan menjaga kepuasan konsumen akan meningkatkan kelangsungan hubungan dengan konsumen lama dan terus membina konsumen baru.

Kondisi pemasaran produk yang sangat dinamis, membuat para pelaku pasar dan produsen berlomba untuk memenangkan kompetisi yang sangat ketat ini. Produk-produk yang ditawarkan begitu beragam dengan kualitas yang juga sangat bervariasi. Peningkatan kualitas produk maupun jasa menjadi masalah yang penting untuk dibicarakan karena dengan kualitas yang baik, suatu produk akan bisa bertahan dalam menghadapi persaingan dan akan diterima oleh konsumen sebagai produk yang mereka harapkan. Salah satu cara memenangkan persaingan adalah dengan berusaha mempertahankan pelanggan yang ada, karena mencari pelanggan yang baru membutuhkan biaya yang lebih besar daripada mempertahankan pelanggan yang ada (Kotler, 1997).

2. Pengaruh Kualitas Pelayanan Terhadap Kepuasan Nasabah BPRS Bangun Drajat Warga Yogyakarta

Hasil pengujian signifikansi menunjukkan bahwa terdapat nilai probabilitas sebesar 0,049 $(0,049<0,05)$. Nilai tersebut dapat membuktikan 
Ha2 diterima, yang berarti bahwa "Kualitas pelayanan berpengaruh terhadap kepuasan nasabah “

Kualitas jasa atau kualitas layanan atau (service quality) berkontribusi signifikan bagi penciptaan diferensiasi, positioning, dan strategi bersaing setiap organisasi pemasaran, baik perusahaan manufaktur maupun penyedia jasa.

Dari hasil penelitian menunjukkan bahwa kualitas layanan berpengaruh positif dan signifikan terhadap kepuasan pelanggan di kolam renang teuku umar bojonegoro. Adanya pengaruh yang signifikan dalam penelitian ini menegaskan bahwa apabila semakin meningkat kualitas pelayanan yang diberikan maka semakin meningkat pula kepuasan pelanggan.

Menurut (Tjiptono, 2002) produk dapat pula diartikan sebagai persepsi konsumen yang dijabarkan oleh produsen melalui hasil produksinya. Oleh karena itu tingkat kepuasan konsumen terhadap suatu produk akan sangat bergantung kepada kualitas produk itu sendiri. Pengaruh Harga Terhadap Kepuasan Nasabah BPRS Bangun Drajat Warga Yogyakarta.

Hasil pengujian signifikansi menunjukkan bahwa terdapat nilai probabilitas sebesar 0,005 $(0,005<0,05)$. Nilai tersebut dapat membuktikan Ha3 diterima, yang berarti bahwa "Harga berpengaruh terhadap kepuasan nasabah".

Harga atau Price adalah nilai suatu barang yang dinyatakan dalam uang (Alma, 2007). Penerapan harga jual berasal dari harga pokok tersebut sedangkan harga pokok barang ditentukan oleh berapa besar biaya yang dikorbankan untuk memperoleh atau untuk membuat barang itu. Harga dapat diartikan sebagai jumlah uang atau satuan moneter dan atau aspek lain (non moneter) yang mengandung kegunaan tertentu yang diperlukan untuk mendapatkan suatu jasa (Tjiptono, 2014).

Penelitian ini sesuai dengan peneitian terdahulu oleh Shandy Widjoyo dengan judul "Pengaruh Kualitas Layanan dan Kualitas Produk Terhadap Kepuasan Pelanggan dan Loyalitas Konsumen Restoran Happy Garden". Penelitian ini bertujuan untuk menganalisa pengaruh dari kualitas layanan dan kualitas produk terhadap kepuasan pelanggan dan loyalitas konsumen di restoran Happy Garden Surabaya serta mengetahui faktor mana yang berpengaruh dominan di restoran tersebut..

3. Variabel yang Paling Dominan Mempengaruhi Kepuasan Nasaabah

Berdasarkan hasil penelitian, hasil yang paling dominan paling mempengaruhi kepuasan nasabah adalah variabel yaitu Kualitas Pelayanan dengan hasil sebesar $0,049(0,049<0,05)$.

4. Pengujian Hasil Simultan

Kualitas produk, kualitas pelayanan, dan harga secara simultan berpengaruh terhadap kepuasan nasabah BPR Syariah Bangun Drajat Warga Yogyakarta. Hal tersebut ditunjukkan oleh hasil pengujian signifikan yang menunjukkan bahwa F hitung sebesar 59,976 dan probabilitas sebesar 
0,000. Karena sig Fhitung $<5 \%(0,000<0,05)$, maka Ha4 diterima dengan demikian hipotesis terbukti.

\section{KESIMPULAN DAN SARAN}

\section{A. Kesimpulan}

Berdasarkan analisis data dan pembahasan yang dilakukan, maka dapat diperoleh kesimpulan sebagai berikut:

1. Pengaruh Kualitas Produk, Kualitas Pelayanan, dan Harga Terhadap Kepuasan Nasabah BPR Syariah Bangun Drajat Warga Yogyakarta Perspektif Ekonomi Islam:

a. Hasil pengujian signifikansi menunjukkan bahwa terdapat nilai probabilitas sebesar 0,047 $(0,047<0,05)$. Nilai tersebut dapat membuktikan $\mathrm{Ha}_{1}$ diterima, yang berarti bahwa "Kualitas Produk berpengaruh terhadap kepuasan nasabah".

b. Hasil pengujian signifikansi menunjukkan bahwa terdapat nilai probabilitas sebesar 0,049 $(0,049<0,05)$. Nilai tersebut dapat membuktikan $\mathrm{Ha}_{2}$ diterima, yang berarti bahwa "Kualitas pelayanan berpengaruh terhadap kepuasan nasabah ".

c. Hasil pengujian signifikansi menunjukkan bahwa terdapat nilai probabilitas sebesar 0,005 $(0,005<0,05)$. Nilai tersebut dapat membuktikan $\mathrm{Ha}_{3}$ diterima, yang berarti bahwa "Harga berpengaruh terhadap kepuasan nasabah ".

2. Variabel yang paling dominan terhadap kepuasan nasabah:

Berdasarkan hasil penelitian, hasil yang paling dominan paling mempengaruhi kepuasan nasabah adalah variabel $X_{2}$ yaitu Kualitas Pelayanan dengan hasil sebesar 0,049 $(0,049<0,05)$.

3. Pengujian Hasil Simultan

Kualitas produk, kualitas pelayanan, dan harga secara simultan berpengaruh terhadap kepuasan nasabah BPR Syariah Bangun Drajat Warga Yogyakarta. Hal tersebut ditunjukkan oleh hasil pengujian signifikan yang menunjukkan bahwa $F$ hitung sebesar 59,976 dan probabilitas sebesar 0,000. Karena sig $F_{\text {hitung }}<5 \%(0,000<0$,05), maka Ha4 diterima dengan demikian hipotesis terbukti..

\section{B. Saran}

Berdasarkan hasil analisis dan kesimpulan maka saran yang dapat diberikan dalam penelitian ini adalah sebagai berikut:

1. Penetapan harga pada BPR Syariah Bangun Drajat Warga Yogyakarta yang menjadi salah satu faktor kepuasan nasabah yang harus masih di perhatikan lagi agar dapat lebih bersaing dengan BPRS lainnya. Berdasarkan hasil data yang telah diolah memiliki hasil sebesar sebesar $0,005(0,005<0,05)$.

2. Pada variabel kualitas layanan diharapkan pengelola BPR Syariah Bangun Drajat Warga Yogyakarta dapat mempertahankan Kualitas Layanan yang sudah baik. 
3. Bagi akademik, bagi peneliti lain yan bermaksud melakukan penelitian di bidang manajemen strategik dan manajemen pemasaran pada suatu perusahaan, diharapkan untuk melakukan penelitian lebih lanjut dan mendalam terkait dengan pengaruh kualitas produk, kualitas pelayanan dan harga terhadap kepuasan nasabah dengan metode penelitian yang sama dan perusahaan yang berbeda guna keberlakuan temuan ini secara lebih luas. Selain itu, penelitian ini perlu dikembangkan dengan mengkaji aspekaspek lain yang mempengaruhi kepuasan nasabah.

\section{Daftar Pustaka}

Arikunto, Suharsimi. 2002. Prosedur Penelitian Suatu Pendekatan Praktek. Jakarta: PT. Rineka Cipta.

Bilsom Simamora. 2002. Panduan Riset Perilaku Konsumen. Surabaya: Pustaka Utama.

Bilsom Simamora. 2003. Panduan Riset Perilaku Konsumen. Jakarta: PT. Gramedia Pustaka Utama.

Buchari Alma. 2000. Manajeman Pemasaran dan Pemasaran Jasa. Bandung: Alfabeta.

Buchari Alma. 2002. Manajeman Pemasaran Jasa. Ypgyakarta: ANDI.

Buchari Alma. 2007. Manajeman Pemasaran dan Pemasaran Jasa. Bandung: CV. Alfabeta

Chandra, Gregorius. 2002. Strategi dan Program Pemasaran. Yogyakarta: Andi Ofset.

Consuegra. D Molina. 2007. An Integrated Model of Price, Satisfaction and Loyality: An Empirical Analysis in Service Sector. Journal of Product \& Brand Managemen.

Didin Hafidudin dan Kendri Tanjung, Manajemen Pemasaran Syariah Dalam Praktik, Gema Insani Impress, Jakarta,2003.

Fandi Tjiptono. 1997. Strategi Pemasaran. Edisi Kedua. Yogyakarta: Andi.

Ferdinand, Augusty. 2006. Metode Penelitian Manajemen. Semarang: BP UNDIP.

Ghozali, Imam. 2009. Aplikasi Analisis Multivariate dengan Program SPSS. Semarang: BP UNDIP.

Henry Simamora. 2000. Basis Pengambilan Bisnis. Jakarta: Salemba Empat.

Hermawan Kertajaya dan M. Syakir Sula, Syariah Marketing, Mizan, Bandung,2006

Kotler, Philip. 1997. Manajeman Pe,asaran, Analisis, Perencanaan, Implementasi dan Kontrol. Edisi Sembilan. Alih Bahasa. Jakarta: PT. Prehallindo.

Kotler, Philip, Benyamin Molan. 2005. Manajemen Pemasaran Jilid 1. Jakarta: INDEKS Kelompok Gramedia.

Kotler, Philip, Gary Armstrong. 2008. Principles of Marketing Thirteenth Edition. New Jersey: Pearson Education, Inc. 
M. Nur Riyanto Al Arif. 2010. Dasar-dasar Pemasaran Bank Syariah. Alfabeta. Bandung.

Malik. Prof. Dr Muhammad Ehsan et al. 2012. Impact of Brand Image, Service Quality, and Price On Customer Satisfaction In Pakistan Telecommunication Sector, International Jurnal of Business and Social Science. Vol.3. No. 23, December 2012.

Philip Kotler, Kevin Lane Keller, Manajemen Pemasaran, Edisi 13 Jilid II,Erlangga,Jakarta,2009.

Stanton, William J. 1998. Prinsip Pemasaran. Jilid Idan II. (Terjemahan: Lamarto). Edisi Ketujuh. Jakarta: Erlangga.

Sudarsono, Henri. 2004. Bank dan Lembaga Keuangan Syariah Deskripsi dan Ilustrasi, Ekonisia. Yogyakarta.

Sugiyono. 2007. Metode Penelitian Pendidikan Pendekatan Kuantitatif, Kualitatif, dan R \& D. Bandung: Alfabeta.

Sugiyono, Dr. 2010. Metode Penelitian Kuantitatif Kualitatif dan R \& D: Alfabeta.

Tjiptono. 2002. Manajeman Jasa. Yogyakarta: Andi.

Tjiptono, Fandy, Anastasia Diana. 2003. Total Quality Management. Yogyakarta: Penerbit Andi.

Tjiptono, Fandy. 2006. Pemasaran Jasa. Malang: Bayumedia Publishing. Tjiptono, Fandy. 2007. Strategi Pemasaran. Yogyakarta: Andi Offset. Tjiptono, Fandy. 2014. Pemasaran Jasa. Jakarta: Gramaedia Cawang. Web site:

http://www.bprs-bdw.co.id/ 